\title{
A new Turonian (Late Cretaceous) species of Inoceramus (Bivalvia) from the Yezo Supergroup, Hokkaido, northern Japan
}

\author{
Akinori Takahashi* \\ Received December 18, 2009. \\ Accepted June 14, 2010 \\ * Department of Earth Sciences, Faculty of Edu- \\ cation and Integrated Arts and Sciences, Wase- \\ da University, 1-6-1 Nishiwaseda, Shinjuku-ku, \\ Tokyo 169-8050, Japan \\ Corresponding author; A. Takahashi, \\ a.takahashi@fuji.waseda.jp
}

\begin{abstract}
A new inoceramid species (Inoceramus nakagawensis sp. nov.) from the Upper Cretaceous Yezo Supergroup, Hokkaido, Japan, is reported and systematically described in detail. The shell sculpture of I. nakagawensis sp. nov. is characterized by very fine, distinct, and regular to somewhat irregular concentric rings. Its occurrence is probably restricted to the upper Lower to lower Middle Turonian, making it a short-ranging species. The present species would be closely allied to Inoceramus cuvieri Sowerby, 1814, from the middle to upper Turonian Stage of Far East Russia.
\end{abstract}

Keywords: biostratigraphy, Cretaceous, inoceramid, Japan, Hokkaido, Turonian, Yezo Supergroup

\section{Introduction}

Inoceramid bivalves (Inoceramidae) are abundant in the Upper Cretaceous Yezo Supergroup (identical to the "Yezo Group" of Takashima et al., 2004), and are useful for intrabasinal stratigraphihc correlation (e.g., Kawabe, 2003; Tsuchiya et al., 2003; Uramoto et al., 2007), occasionally interbasinal correlation (e.g., Toshimitsu et al., 1995), owing to their rapid evolution and speciation, and relatively wide biogeographic distribution. Therefore, the discovery of a new short-ranging species allows for progress in biostratigraphy and allied fields.

I collected a few strange inoceramid specimens (Inoceramus aff. concentricus of Takahashi et al., 2003) along the Chirashinai River of the Teshionakagawa area, northern Hokkaido (Fig. 1), where the Middle Yezo Group of the Yezo Supergroup is widely distributed. Afterward, it became clear for these specimens to belong to a new Turonian species. Here, systematic paleontological and biostratigraphic significances of Inoceramus nakagawensis sp.nov. are described in the present study. The specimens described and figured herein are registered and housed at Waseda University, with the prefix WE. B.

\section{Geological setting}

The Yezo Supergroup is widely distributed in central Hokkaido Island. It is a thick terrigenous clastic succession consisting of mudstone, sandstone and conglomerate beds, which were deposited in the Aptian to Paleocene forearc basin of the East Asian active margin that is exposed on Hokkaido and Sakhalin (Far East Russia) Islands (e.g., Okada, 1982; Takashima et al., 2004). The total thickness of the supergroup is about $10,000 \mathrm{~m}$ in maximum. The Yezo Supergroup is divided into four groups, namely the Lower Yezo, Middle Yezo, Upper Yezo and Hakobuchi groups (Matsumoto, 1951; Okada, 1983).

The Middle Yezo Group in the Teshionakagawa area, northern Hokkaido, is subdivided into five formations, namely the Moehoro, Shirataki, Sakotandake, Sakugawa and Saku formations, in ascending stratigraphic order (Kawaguchi, 1997; Takahashi et al., 2003, 2007). New inoceramid specimens reported herein were discovered from the Sakugawa Formation exposed along the Chirashinai River in the Teshionakagawa area (loc. N15033 of Fig. 1). The Sakugawa Formation, which is composed mainly of siltstone and sandy siltstone beds, is correlated with the Cenomanian to the Middle Turonian (Takahashi et al., 2003). A Turonian ammonite, Mesopuzosia pacifica Matsumoto, occurs in the same horizon as the inoceramid specimens.

\section{Systematic Paleontology}

Family Inoceramidae Giebel, 1852

Genus Inoceramus Sowerby, 1814

Type species.- Inoceramus cuvierii Sowerby, 1814 (Cox, 1969, p. N315 by subsequent designation).

Remarks.-Inoceramus (s.l.) has been subdivided into many subgenera, such as Inoceramus, Cremnoceramus, Cordiceramus, Cladoceramus, Platyceramus, and Volviceramus etc. (e.g., Noda, 1986, 1996; Toshimitsu, 1986; Noda and Matsumoto, 1998; Noda, 2002). On the other hand, those subgenera are currently ranked as the independent genera (e.g., Dhondt, 1992; Voigt, 1995; Takahashi, 2005; Kauffman et al., 2007; Kennedy et al., 


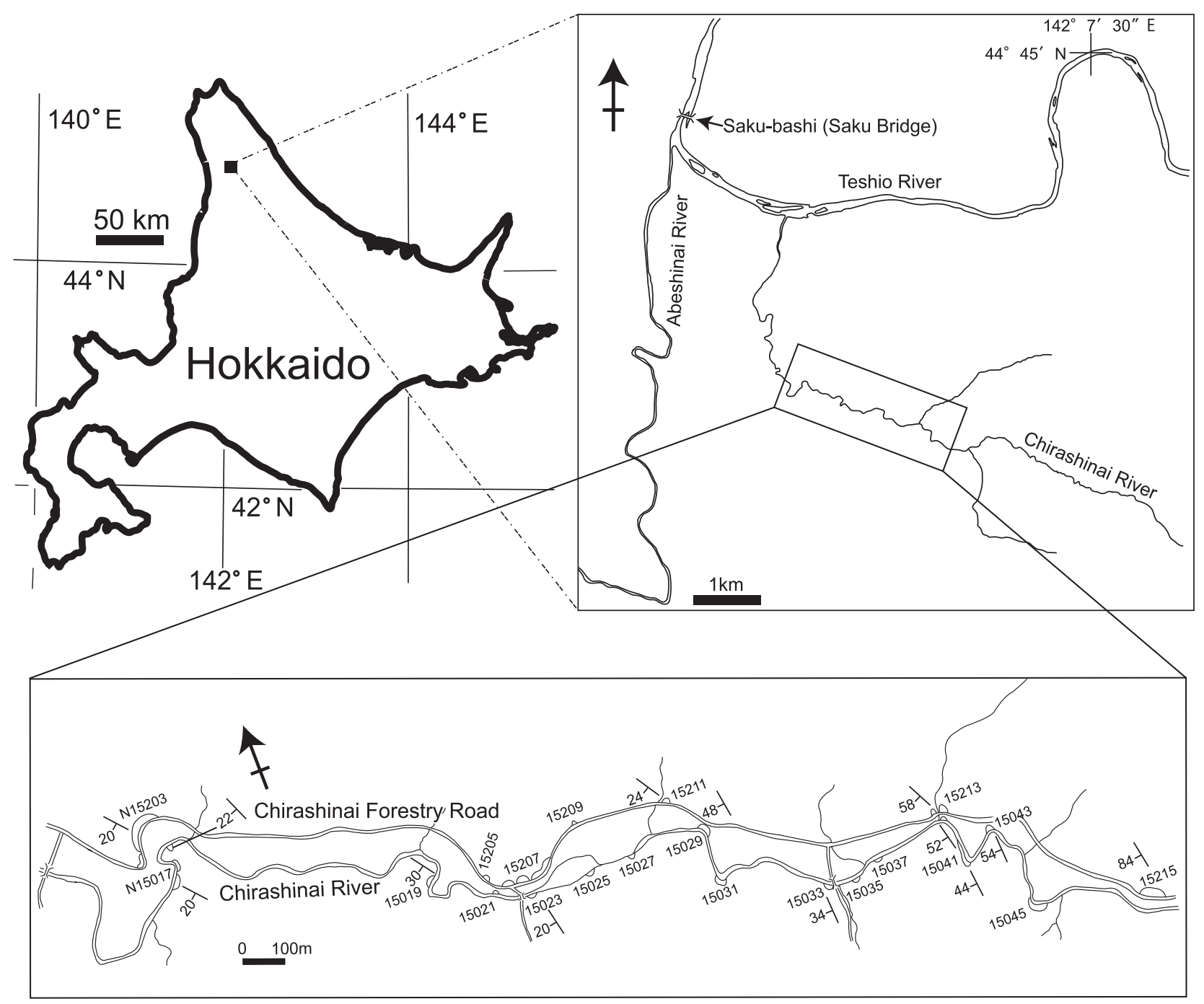

Fig. 1. Index and route maps along the Chirashinai River in the Teshionakagawa area of Hokkaido, northern Japan. Inoceramus nakagawensis sp. nov. has been found at the loc. N15033 along the Chirashinai River. Prefix "N" is omitted in each locality number.

2008) in the Family Inoceramidae, because those genera are clearly distinguishable each other based on morphological characters of the shell. The present new inoceramid species described here is erect-ovate to elliptic outline, subequivalve, and growth axis does not extremely bend. In addition, that has projecting beak. Since those characters are peculiar to the genus Inoceramus (s.s.) (Harries et al., 1996), I assign the following new species to the genus Inoceramus (s.s.).

\section{Inoceramus nakagawensis sp. nov.}

Figure 2

Material.- Holotype (WE. B. 0001) and paratypes are from loc. N15033 of Takahashi et al. (2003, 2007) (Fig. 1). A holotype (WE. B. 0001) and all paratypes (WE. B. 00020004) are at Waseda University.
Etymology.- The present species is named after Nakagawa Town, Hokkaido Island, in which the type locality is situated.

Diagnosis.- Adult shell very small in size, inequilateral, rounded to parabolical (somewhat nearly mytiliform) in outline, with growth axis convex toward the dorsal margin. Shell surface characterized by very fine, distinct, and regular to somewhat irregular concentric rings and very weakly concentric ribs.

Description.- Adult shell very small in size, inequilateral, prosocline, slightly higher than long (Table 1), rounded to parabolical in outline, obliquity $(\delta)$ weak to moderate (Table 1), with growth axis convex toward posterior margin. Subequivalve or maybe slightly inequivalve. Umbo terminal, prominent and incurved. Anterodorsal margin slightly to moderately concave, and anteroventral margin slightly to moderately rounded, passing into 
Table 1. Measurements on the type specimens. h: shell height, l: shell length, H: maximum linear dimension from umbo to ventral extremity, $\mathrm{L}$ : maximum linear dimension perpendicular to $\mathrm{H}$, b: shell breadth, s: length of hinge line, (h-s: in mm), $\alpha$ : angle between anterodorsal margin and hinge line, $\beta$ : beak angle, $\gamma$ : angle between posterodorsal margin and hinge line, $\delta$ : obliquity, ( $\alpha-\delta$ : in degrees)

\begin{tabular}{llllllllllllll}
\hline \hline Specimens & $\mathrm{h}$ & $\mathrm{I}$ & $\mathrm{l} / \mathrm{h}$ & $\mathrm{H}$ & $\mathrm{L}$ & $\mathrm{L} / \mathrm{H}$ & $\mathrm{b}$ & $\mathrm{s}$ & $\mathrm{s} / \mathrm{l}$ & $\alpha$ & $\beta$ & $\gamma$ & $\delta$ \\
\hline WE.B. 0001 (holotype) (R) & 15.00 & 12.25 & 0.82 & 15.50 & 12.70 & 0.82 & 6.20 & 3.95 & 0.32 & 108 & 93 & - & 62 \\
WE.B. 0002 (paratype) (R) & - & - & - & 17.80 & 8.15 & 0.46 & 5.00 & - & - & - & 67 & - & - \\
WE.B. 0003 (paratype) (R) & - & - & - & 20.60 & 11.75 & 0.57 & 8.05 & - & - & - & 105 & - & - \\
WE.B. 0004 (paratype) (L) & 15.50 & 11.25 & 0.73 & 17.85 & 14.25 & 0.80 & 5.80 & 7.60 & 0.68 & 110 & 72 & 113 & 70 \\
\hline
\end{tabular}

rounded ventral margin, with narrow to moderately broad ventral area. Posteroventral margin weakly to fairly rounded, passing into posterodorsal margin that is weakly rounded to nearly straight. Valve slightly to greatly inflated, with convexity relatively uniform along growth lines. Ornamentation consists of very fine, distinct, closely and regularly to somewhat irregularly spaced concentric rings, and very weakly concentric ribs.

Measurements.- See Table 1.

Intrapopulational variation.- The present new species shows some extent of morphological variation. The shell outline is rounded, parabolical to somewhat mytiliform, but the outline of the specimen of WE. B. 0004 (left valve) is exceptionally nearly square. All specimens are ornamented by fine concentric rings, both the outer shell surface (WE. B. 0001, 0002) and internal mold (WE. B. 0003, 0004). Although the concentric rings are rather regular, the specimen of WE. B. 0003 is ornamented by irregular rings. Very weak concentric ribs appear in the holotype (WE. B. 0001).

Comparison.- The present specimens are characterized by very fine and distinct concentric rings. Inoceramus sorachiensis Noda and Matsumoto MS (see Noda, 2002; Tanaka and Toshimitsu, $2003=I$. concentricus var. costatus Nagao and Matsumoto, 1939, and I. costatus of Toshimitsu et al., 1995), which has not been formally described and is an invalid biological name, somewhat resembles the present species in its small adult size and the shell outline. I. sorachiensis MS is an important index species for the lower Middle Turonian (fig. 1 in Toshimitsu et al., 1995), so may be related to phylogenetically $I$. nakagawensis sp. nov. However, I. nakagawensis sp. nov. can be distinguished from I. sorachiensis MS by having much fine and distinct concentric rings. Contrary, the shell ornamentation of $I$. sorachiensis MS is characterized by coarser concentric ribs. Therefore, I. sorachiensis MS is not a valid name. This allied but different species is needed to be formally described as I. sorachiensis in future.

The specimens of I. nakagawensis sp. nov. described above would be closely allied to Inoceramus cuvieri
Sowerby, 1814, from the middle to upper Turonian Stage of Central Asia, India, Western Interior Seaway, Europe and Far East Russia (see Crampton, 1996). Pergament (1971) reported the occurrence of I. cuvieri and described the species from southern Sakhalin and Kamchatka (Far East Russia). I. cuvieri is similar to I. nakagawensis sp. nov. in the whole outline and the shape of the beak. However, I. nakagawensis sp. nov. has much finer concentric rings and does not have a broad posterior wing, while I. cuvieri shown in Pergament (1971) does not have such fine, distinct and regular concentric rings and has a broad posterior wing. I. nakagawensis sp. nov. also resembles $I$. aff. cuvieri in Zonova (1992; pl. 85, figs. 1-3) from the $I$. hobetsensis Zone in Kamchatka in the overall outline and the curvature of the concentric ribs. However, I. nakagawensis sp. nov. has much finer concentric rings and does not have a broad posterior wing compared with Zonova's specimens. In addition, illustrated speciemens by Zonova (1992) have a little broader beak angle. A speciemen of pl. 36, fig. 1 of $I$. aff. cuvieri seen in Zonova (1993) from Sakhalin, Far East Russia is similar to $I$. nakagawensis sp. nov. in having the relatively regular concentric rings. However, the figured specimen (I. aff. cuvieri) by Zonova (1993) is a more quadrilateral outline and the curvature of concentric rings is gentler, so the overall outline is rather different from that of $I$. nakagawensis sp.nov. Moreover, the present new species bears a resemblance to a specimen of pl. 36, fig. 3 of $I$. aff. cuvieri in Zonova (1993). However, the anterodorsal margin of the Russian specimen is not concave and the specimen does not have the fine concentric rings; besides, the curvature of concentric ribs of the Russian specimen is gentler, and the overall shell-outline is more quadrilateral. In summary, I. nakagawensis sp. nov. can be distinguished from $I$. aff. cuvieri seen in Zonova $(1992,1993)$ based on investigation of the above-mentioned characters and from other related species.

Furthermore, I. pseudocuvieri Pergament, 1971 seen in Zonova (1987) is very similar to I. nakagawensis sp. nov. in the parabolical to mytiliform outline, and the curvature of concentric rings, but I. pseudocuvieri has a 

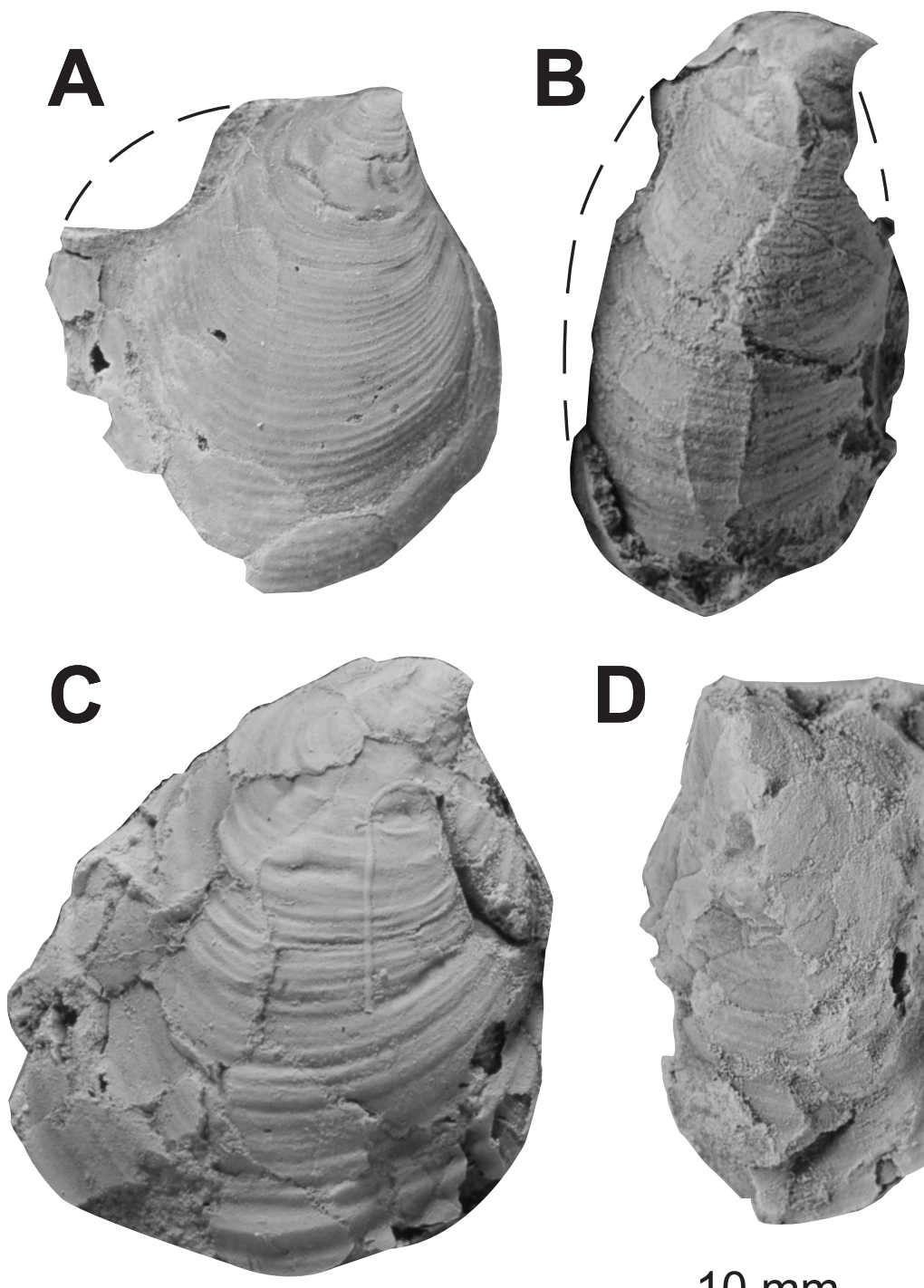

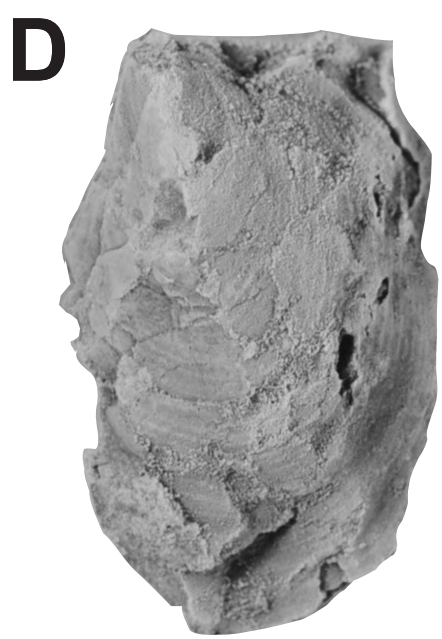

$10 \mathrm{~mm}$

Fig. 2. Photographs of Inoceramus nakagawensis sp. nov. A: Holotype (WE. B. 0001), right valve, external shell surface. B: Paratype (WE. B. 0002), right valve, external shell surface. C: Paratype (WE. B. 0003), right valve, internal mold. D: Paratype (WE. B. 0004), left valve, internal mold.

broad posterior wing and has more widely-spaced irregular concentric rings. These points are conclusive distinction between two species.

Occurrence.- Probably the uppermost Lower to lowest Middle Turonian Substage (discussed below in detail), where it co-occurs with the ammonite Mesopuzosia pacifica Matsumoto in the Sakugawa Formation of the Middle Yezo Group in the Teshionakagawa area, northern Hokkaido Island, Northern Japan (Figs. 1, 3).

\section{Stratigraphic occurrence}

Inoceramus nakagawensis sp. nov. occurs near the first appearance datum of the ammonite Mesopuzosia pacifica in the Teshionakagawa area (loc. N15033; Figs. 1, 3). Although M. pacifica is a long-ranging species, and has been reported from the upper Upper Cenomanian to
Upper Turonian of Japan (Toshimitsu and Hirano, 2000), the species is most abundant from the Middle Turonian (e.g., Toshimitsu et al., 1995; Asai and Hirano, 1990; Kawabe, 2000). Therefore, the stratigraphic level occurring I. nakagawensis sp. nov. in the Teshionakagawa area presumably belongs to the Kossmaticeras flexuosum M. pacifica Biozone (Middle Turonian) of Toshimitsu et al. (1995). I. nakagawensis sp. nov. probably occurs in the upper Lower Turonian to lower Middle Turonian. In addition, Inoceramus kamuy Matsumoto and Asai, an age-diagnostic Lower Turonian species (e.g., Matsumoto and Asai, 1996), occurs at loc. N15035, whose horizon is 35-40 m below that of loc. N15033 (Fig. 3). These also support the above view. In summary, I. nakagawensis sp. nov. seems to be a short-ranging species to the upper Lower -lower Middle Turonian (Fig. 3). Further studies on 


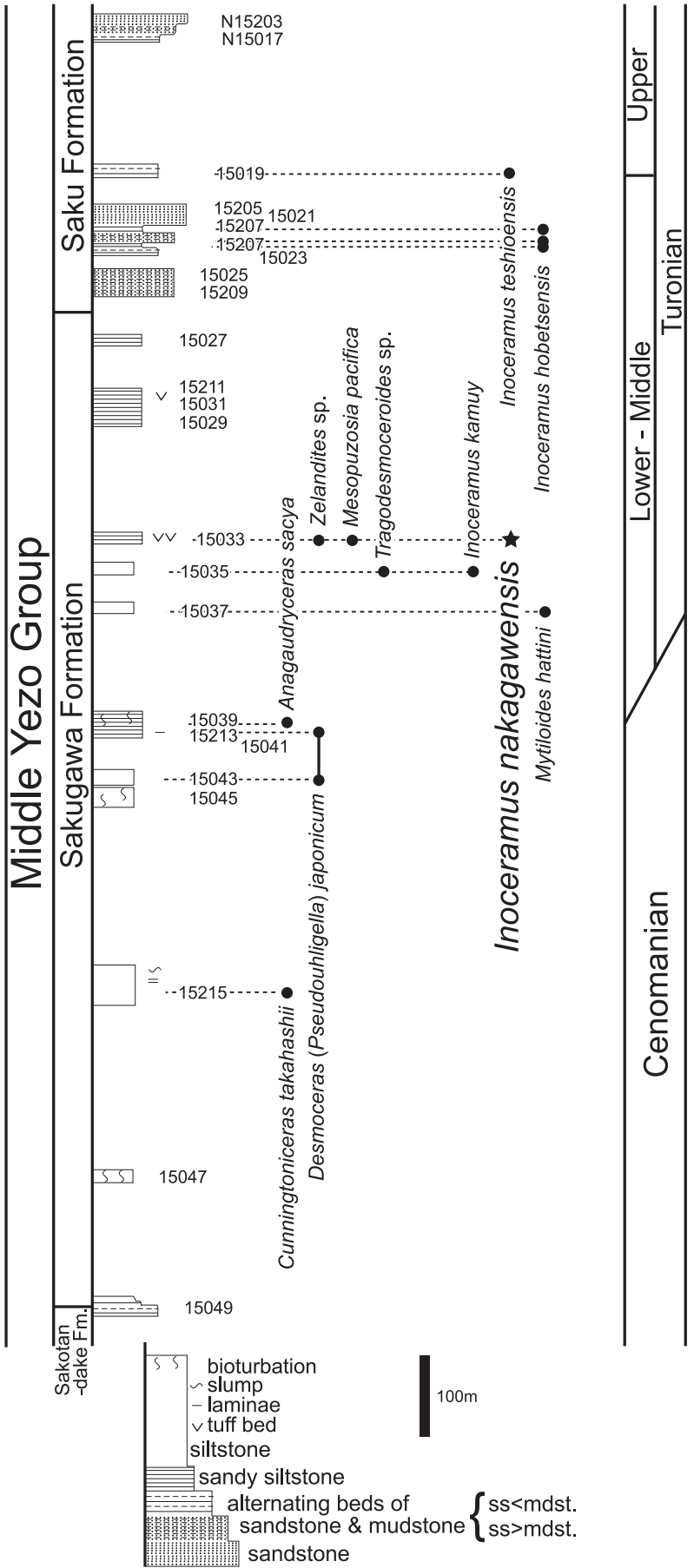

Fig. 3. Composite columnar section and stratigraphic distribution of ammonoids and inoceramid bivalves along the Chirashinai River and its Forestry Road. Prefix "N" is omitted in each locality number.

the exact stratigraphic and geographic distribution of the new species are required, in order to test usability of $I$. nakagawensis sp. nov. in stratigraphic correlation.

\section{Acknowledgments}

I am most grateful to Professors Hiromichi Hirano (Waseda University), Kazushige Tanabe, Tatsuo Oji (Uni- versity of Tokyo) and Ireneusz Walaszczyk (University of Warsaw) for many fruitful suggestions. I also wish to thank Dr. Yoshinori Hikida (Nakagawa Museum of Natural History) for providing data on local geology. I am very grateful for the constructive remarks of the Corresponding Editor (Dr. Yasunari Shigeta) and reviewers (Dr. Haruyoshi Maeda and Dr. Seiichi Toshimitsu). This work has been financially supported by the Waseda University Grant for Special Research Projects (2006A-846 and 2007A-042).

\section{References}

Asai, A. and Hirano, H., 1990, Stratigraphy of the Upper Cretaceous in the Obira area, Northwestern Hokkaido. Gakujutsu Kenkyu, Sch. Edu., Waseda Univ., Ser. Biol. Geol., 39, 37-50.

Cox. L. R., 1969, Family Inoceramidae Giebel, 1852. In Moore, R. C., Teichert, C., McCormick, L. and Williams, R. B., eds., Treatise on Invertebrate Paleontology, Part N, 1, Mollusca 6, Bivalvia, Univ. of Kansas Press and Geol. Soc. of Amer., Lawrence, KS, N314-N321.

Crampton, J. S., 1996 ed., Inoceramid bivalves from the Late Cretaceous of New Zealand. Inst. of Geol. and Nucl. Sci. Monogr., no. 14 (N. Z. Geol. Surv. paleont. Bull., no. 70), Inst. of Geol. and Nucl. Sci., Lower Hutt, N. Z. 192 p.

Dhondt, A. V., 1992, Cretaceous inoceramid biogeography: a review. Palaeogeogr. Palaeoclimatol. Palaeoecol., 92, 217-232.

Giebel, C. G., ed., 1852, Allgemeine Palaeontologie: Entwurf einer systematischen Darstellung der Fauna und Flora der Vorwelt, Leipzig, Ambrosius Abel. 413 p.

Harries, P. J., Kauffman, E. G., Crampton, J. S., Bengtson, P., Cech, S., Crame, J. A., Dhondt, A. V., Ernst, G.., Hilbrecht, H., Lopez, G., Mortimore, G. R., Tröger, K.-A., Walaszcyk, I. and Wood, C. J., 1996, Lower Turonian Euramerican Inoceramidae: a morphorogic, taxonomic, and biostratigraphic overview; a report from the first workshop on early Turonian inoceramids (Oct. 5-8, 1992) in Hamburg, Germany; organized by Heinz Hilbrecht and Peter J. Harries. Mitteilungen aus dem Geologisch-Paläontologischen Museum der Universität Hamburg (Proc. 4th Intern. Cret. Symp.), 77, 641671.

Kauffman, E. G., Harries, P. J., Meyer, C., Villamil, T., Arango, C. and Jaecks, G., 2007, Paleoecology of giant Inoceramidae (Platyceramus) on a Santonian (Cretaceous) seafloor in Colorado. Jour. Paleont., 81, 64-81.

Kawabe, F., 2000, Cretaceous stratigraphy in the Oyubari area, central Hokkaido, Japan. Bull. Natn. Sci. Mus., Tokyo, Ser. C, Geol., 26, 956.

Kawabe, F., 2003, Relationship between mid-Cretaceous (upper AlbianCenamanian) ammonoid facies and lithofacies in the Yezo forearc basin, Hokkaido, Japan. Cret. Res., 24, 751-763.

Kawaguchi, M., 1997, Lower Cretaceous strata around the River Onisashi, northern Hokkaido. In Kawamura, M., Oka, T. and Kondo, T., eds., Prof. Makoto Kato Mem. Vol., Hokkaido Univ., Sapporo, Hokkaido. 121-134.*

Kennedy, W. J., Walaszczyk, I. and Klinger, H. C., 2008, Cladoceramus (Bivalvia, Inoceramidae)-ammonite associations from the Santonian of KwaZulu, South Africa. Cret. Res., 29, 267-293.

Matsumoto, 1951, The Yezo Group and the Kwanmon Group. Jour. Geol. Soc. Japan, 57, 95-98.*

Matsumoto, T. and Asai, A., 1996, An early Turonian (Cretaceous) new species of Inoceramus (Bivalvia) from Hokkaido. Trans. Proc. Palaeont. Soc. Japan, New Ser., no. 181, 375-387.

Nagao, T. and Matsumoto, T., 1939, A monograph of the Cretaceous Inoceramus of Japan. Part I. Jour. Fac. Sci., Hokkaido Imp. Univ. Ser. IV, 4, 241-299.

Noda, M., 1986, A new species of Inoceramus (Cordiceramus) (Bivalvia) from the Upper Coniacian (Cretaceous) of Hokkaido. Trans. Proc. 
Palaeont. Soc. Japan, New Ser., no. 142, 354-365.

Noda, M., 1996, Five inoceramids (Bivalvia) from the Upper Cretaceous of Hokkaido with some phylogenetic and taxonomic considerations. Trans. Proc. Palaeont. Soc. Japan, New Ser., no. 184, 555-591.

Noda, M., ed., 2002, Catalogue of the inoceramid specimens donated from the Jonan Geological Association, Oita to the Kyushu University Museum, Fukuoka. Spec. Issue Geol. Soc. Oita, no. 7, 199 p. **

Noda, M. and Matsumoto, T., 1998, Palaeontology and stratigraphy of the inoceramid species from the mid-Turonian through upper Middle Coniacian in Japan. Acta Geol. Polonica, 48, 435-482.

Okada, H., 1982, Geological evolution of Hokkaido, Japan: an example of collision orogenesis. Proc. Geol. Assoc., 93, 201-212.

Okada, H., 1983, Collision orogenesis and sedimentation in Hokkaido, Japan. In Hashimoto, M. and Uyeda, S., eds., Accretion Tectonics in the Circum-Pacific Regions, Terra Sci. Publ. Co., Tokyo, 91-105.

Pergament, M. A., ed, 1971, Biostratigraphy and inocerams of TuronianConiacian deposits of the Pacific regions of the USSR. Trans. Akademii Nauk SSSR, 212 p.***

Sowerby, J., ed, 1814, Article XI, Linnaean Society. Ann. Phil., London. 4, $448 \mathrm{p}$.

Takahashi, A., 2005, Diversity changes in Cretaceous inoceramid bivalves of Japan. Paleont. Res., 9, 217-232.

Takahashi, A., Hikida, Y., Jenkins, R. G. and Tanabe, K., 2007, Stratigraphy and megafauna of the Upper Cretaceous Yezo Supergroup in the Teshionakagawa area, northern Hokkaido, Japan. Bull. Mikasa City Mus. , no. 11, 25-59.

Takahashi, A., Hirano, H. and Sato, T., 2003: Stratigraphy and fossil assemblage of the Upper Cretaceous in the Teshionakagawa area, Hokkaido, northern Japan. Jour. Geol. Soc. Japan, 109, 77-95.*

Takashima, R., Kawabe, F., Nishi, H., Moriya, K., Wani, R. and Ando, H., 2004, Geology and stratigraphy of forearc basin sediments in Hokkaido, Japan: Cretaceous environmental events on the north-west Pacific margin. Cret. Res., 25, 365-390.

Tanaka, H. and Toshimitsu, S., 2003, Cretaceous Bivalvia. In Ikeya, N.,
Hirano, H. and Ogasawara, K., eds., The database of Japanese fossil type specimens described during the 20th Century (Part 3), Palaeont. Soc. Japan, Spec. Pap., Tokyo, no. 41, 192-276.

Toshimitsu, S., 1986, A new inoceramid (Bivalvia) species from the Upper Cretaceous of Hokkaido. Proc. Japan Acad., Ser. B, 62, 227-230.

Toshimitsu, S. and Hirano, H., 2000, Database of the Cretaceous ammonoids in Japan -stratigraphic distribution and bibliography-. Bull. Geol. Surv. Japan, 51, 559-613.

Toshimitsu, S., Matsumoto, T., Noda, M., Nishida, T. and Maiya, S., 1995, Towards an integrated mega-, micro- and magneto-stratigraphy of the Upper Cretaceous in Japan. Jour. Geol. Soc. Japan, 101, 19-29.*

Tsuchiya, K., Hasegawa, T. and Pratt, L. M., 2003, Stratigraphic relationship between diagnostic carbon isotope profiles and inoceramid biozones from the Yezo Group, Hokkaido, Japan. Jour. Geol. Soc. Japan, 109, 30-40.*

Uramoto, G.-I., Fujita, T., Takahashi, A. and Hirano, H., 2007, Cenomanian (Upper Cretaceous) carbon isotope stratigraphy of terrestrial organic matter for the Yezo Group, Hokkaido, Japan. Island Arc, 16, 465478.

Voigt, S., 1995, Palaeobiogeography of early Late Cretaceous inoceramids in the context of a new global palaeogeography. Cret. Res., 16, 343356.

Zonova, T. D., 1987, Systematics, Chapter 1, Inoceramids. In Poyarkova, Z. N. ed., Reference Section of Cretaceous Deposits in Sakhalin (Naiba section), Leningrad Nauka Publ. Leningrad, 104-129.**

Zonova, T. D., 1992, Inoceramids. In Zonova, T. D. and Rostovcev, K. O., eds., Atlas of the Key Groups of the Mesozoic Fossils of the Southerm and Easterm Parts of the USSR. St. Petersburg. 175-191.***

Zonova, T. D., 1993, Inoceramids. In Zonova, T. D. and Zhamoida, A. I., eds., Atlas of the Key Groups of the Cretaceous Fossils of Sakhalin, St. Petersburg. 85-143. ${ }^{* * *}$

$*$ : In Japanese with English abstract

**: In Japanese

***: In Russian

（要 旨）

Takahashi, A., 2010, A new Turonian (Late Cretaceous) species of Inoceramus (Bivalvia) from the Yezo Supergroup, Hokkaido, northern Japan. Jour. Geol. Soc. Japan, 116, 412417. （高橋昭紀，2010，北海道蝦夷超層群から産出したチューロニアン期（後期白覀紀） のイノセラムス類 (二枚貝網) の 1 新種. 地質雑, 116, 412-417)

本邦北海道に分布する上部白西系蝦夷超層群中部蝦夷層群産の新種のイノセラムス類 1 種を記載した. 本種の産出層準は，下部チューロニアン階上部から中部チューロニアン階下 部と考えられ，表面装飾は非常に細かく明瞭な，規則正しい（一部不規則な）同心円輪で特 徵付けられる。本種は, 極東ロシア（サハリンやカムチャツカ半島）で産出している Inoceramus cuvieri Sowerby, 1814 に近縁であると考えられる. 